\title{
Analysis of Assertive Communication Skills in Adolescents Health With Aggressive Behavior
}

\author{
Endang Mei Yuliani* \\ Faculty of Health Sciences \\ Kadiri University, Indonesia. \\ endang.mei@unik-kediri.ac.id
}

\author{
Arif Nurma Etika \\ Faculty of Health Sciences \\ Kadiri University, Indonesia. \\ arif.etika@unik-kediri.ac.id \\ Satria Eureka Nurseskasatmata \\ Faculty of Health Sciences \\ Kadiri University, Indonesia \\ satria.en@unik-kediri.ac.id
}

\author{
Idola Perdana Sulistyoning Suharto \\ Faculty of Health Sciences \\ Kadiri University, Indonesia. \\ idolaperdana@unik-kediri.ac.id
}

\begin{abstract}
Communication is the basis of all social interaction activities in life. One of the important abilities for humans to have as social creatures is assertive communication skills. Assertive communication is the ability to convey thoughts, feelings, needs while still paying attention to the rights of others. Lack of assertive communication skills in adolescents is one of the causes of aggressive behavior. An initial survey conducted on a number of junior high school students who had aggressive behavior showed the lack of assertive communication skills possessed. This study aims to describe assertive communication skills in early adolescents who have aggressive behavior, using the Assertiveness Scale for Adolescents (ASA). This research is a descriptive study with a sample of 147 adolescents selected using the purposive sampling method. The results showed the highest communication skills were aggressive communication $(59.9 \%)$, unassertive or passive communication $(26.5 \%)$, the lowest communication ability was assertive communication (13.6\%). This research recommends that parents and schools are important to continue to provide assertive communication stimulation in adolescents.
\end{abstract}

Keywords: aggressive, assertive communication, behavior, adolescents

\section{INTRODUCTION}

Adolescence is a period of transition in individuals characterized by physical and emotional or psychological changes [1]. Entering adolescence or puberty, for some adolescents is defined as a difficult period and a period that affects the physical and psychological state of adolescents [2]. One aspect that stands out during adolescent development is the development of emotional aspects [3]. Emotion is the body's reaction as feedback to a condition due to the emergence of a stimulus that causes changes in adolescent behavior [4]. Changes in emotions during adolescence cause individuals to have a high curiosity about the surrounding environment as well as being vulnerable in distinguishing between good and bad [5]. The consequences that occur if adolescents find it difficult to distinguish positive or negative things, one of which is that adolescents can become people who rebel or engage in aggressive behavior [5].
Aggressive behavior is one form of individual emotional expression due to a lack of success [6]. This behavior can be embodied in the form of damaging objects or conducting attacks on others either verbally or non-verbal which is done with an element of intent [7]. This aggressive behavior is one of the most common problems in teenagers [6]. The impact of this aggressive behavior can cause harm to individuals who conduct aggressive behavior or individuals who receive aggressive behavioral treatment [8]. The World Health Organization (WHO) mentions that Non Communicable Disease is the trend and issue of World health problems, including in Southeast Asia [9] [10]. The Data from the WHO mentions that $11.7 \%$ of adolescents were exposed to liquor, resulting from the consumption of this liquor could cause adolescents to commit violent acts (National Conference on Mental Health Nursing, 2018).

A study conducted by Hsiao, Cheng, and Chiu explained that aggressive behavior was instrumental in the youth's development. This aggressive behavior is associated with behavioral issues such as anxiety, depression, suicide trials, social isolation, and violent behavior [11], meaning that if aggressive behavior in adolescents is not detected as early as possible and not obtained the right treatment, it can cause mental disorders [12]. The World Health Organization (WHO) estimates that the number of teenagers in the world is around $1 / 5$ (one fifth) of the total world population, this situation in the last few years has caused a shift in the pattern of causes of crime. The number of teenagers in Indonesia shows a quite large number, reaching 63.4 million people or $26.7 \%$ of the total population. Data in East Java alone shows that the proportion of adolescent population shows $16.19 \%$ of the total population $(6,133,053$ inhabitants) [13]. This illustrates the risk of increasing violations of the law [14].

The Indonesian Children Protection Commission (KPAI) in 2011 - 2016 mentioned the case of adolescent-related laws was increasing. Such Data are the case of physical violence and psychic violence which is a form of aggressive behavior [15]. In 2016 there were 298 cases of juvenile delinquency and among them were physical violence cases. The Data show an increasing compared to the case in 2015 
[16]. 554 cases of persecution at the age of youth were found in East Java in 2014, the case was higher than the previous year, 484 cases [2]. and in the report on the performance of government maintenance, East Java provincial government mention that the case of juvenile delinquency in East Java is still high [17]. The results of the initial survey conducted by researchers in SMP 8 Kediri obtained data that from 14 students, 7 of whom often do aggressive behavior in the form of speech/verbal such as threatening a friend if his wishes are not met, ridicule banter, and insinuate to other. In addition, some students also have a history of committing physical violence, such as kicking or hitting a friend when angry. Those data show the high incidence of aggressive behavior on the stage of adolescent age. Aggressive behavior carried out by adolescents is a representation of behavior and communication that is not assertive.

Assertiveness is an interpersonal behavior that involves aspects of openness and honesty of thoughts and feelings [18]. According to Albert and Emmons assertive communication is the ability of individuals to express their feelings, ask for what they want and be able to say "no" about a thing. Individuals are able to be assertive and able to hold good social relationships [19]. Teenagers who have assertive communication skills can optimize their potential. Conversely, the inability to make assertive communication can cause obstacles in establishing interpersonal relationships due to the lack of ability to express personal expectations to others [20]. The phenomenon found, still high adolescents who show behavior that represents low assertive communication skills, researchers are interested in conducting research that aims to find out about assertive communication skills in early adolescents who have aggressive behavior. Researchers will explain about assertive communication skills based on the categorization of Assertiveness Scale for Adolescents (ASA).

\section{METHOD}

This research is a type of qualitative research. This research was conducted at SMP 8 Kediri in 2019. This research was a quantitative descriptive study using purposive sampling method, with respondents' inclusion criteria: 1) Adolescents aged 13-15 years, 2) Middle School students, 3) Having a history or behavioral experience aggressive. As for the exclusion criteria, namely: 1) Students who cannot do physical activity, 2) Decide not to continue filling out the questionnaire, or not complete the questionnaire in full. The selection of respondents was conducted in May 2019 in class VIII of SMP 8 Kediri consisting of 11 classes with a total of 319 students. Of 319 students, 147 students were found with experience of aggressive behavior. The instrument used to measure assertive communication skills is the Assertiveness Scale for Adolescents (ASA). The results of the product moment value of 0.798 and $r$ table 0.444 so that the question items declared valid. The reliability test results obtained cronbach's alpha coefficient value 0.957 with $r$ table 0.444 , so the instrument was declared reliable. The Assertiveness Scale for Adolescents instrument has three elements of questions, namely questions about the ability to express positive feelings, the ability to express negative feelings / ability to say no and the ability to defend personal rights contained in 33 question items. The results of the ASA questionnaire were further divided into 3 categories namely assertive communication, passive communication and aggressive communication

The study was conducted in May to July 2019 in SMP 8 Kediri. Before the researcher begins the research by providing an explanation of the purpose of the study, then the researcher provides an informed consent sheet that needs to be signed by the respondent if the prospective respondent is willing to become a respondent. After the respondent signs the informed consent sheet, the researcher gives a questionnaire to assess the assertive communication ability of the respondent.

\section{RESULT AND DISCUSSION}

\section{A. Respondents Characteristics.}

\begin{tabular}{|c|c|c|}
\hline Characteristics & Frequency & Percentage \\
\hline \multicolumn{3}{|l|}{ Gender } \\
\hline Male & 75 & 51,1 \\
\hline Female & 72 & 48,9 \\
\hline Total & 147 & 100 \\
\hline \multicolumn{3}{|l|}{ Age } \\
\hline 13 years old & 44 & 29,9 \\
\hline 14 years old & 101 & 68,7 \\
\hline 15 years old & 2 & 10,1 \\
\hline Total & 147 & 100 \\
\hline \multicolumn{3}{|l|}{$\begin{array}{c}\text { Closest People in the } \\
\text { Family }\end{array}$} \\
\hline Father & 23 & 15,6 \\
\hline Mother & 31 & 21,1 \\
\hline Father and Mother & 84 & 57,1 \\
\hline Others & 9 & 6,12 \\
\hline Total & 147 & 100 \\
\hline \multicolumn{3}{|l|}{ Residence } \\
\hline With parents & 121 & 82,3 \\
\hline Without parents & 26 & 17,7 \\
\hline Total & 147 & 100 \\
\hline \multicolumn{3}{|l|}{$\begin{array}{l}\text { The existence of a } \\
\text { close friend }\end{array}$} \\
\hline There are close friends & 129 & 87,8 \\
\hline Without close friends & 18 & 12,2 \\
\hline Total & 147 & 100 \\
\hline
\end{tabular}

Based on table 1, it can be seen that there are equal proportions between the number of male and female respondents with the majority of respondents aged 14 years. Based on the closest relationship in the family, most respondents have closeness with both parents or father and mother at the same time, namely 84 respondents $(57.1 \%)$. Where almost all respondents lived with parents, there were 121 respondents $(82.3 \%)$. In addition, due to interpersonal relationships, almost all respondents had close friends, namely 129 respondents $(87.8 \%)$.

\section{B. Description of Assertive Communication Ability}

Table 2. Assertive Communication Skills of Respondents

\begin{tabular}{cccc}
\hline No & Category & F & $\%$ \\
\hline 1 & $\begin{array}{c}\text { Aggressive } \\
\text { Communication }\end{array}$ & 98 & 66,7 \\
\hline
\end{tabular}




\begin{tabular}{cccc}
\hline 2 & $\begin{array}{c}\text { Passive } \\
\text { Communication }\end{array}$ & 31 & 21,1 \\
\hline 3 & $\begin{array}{c}\text { Assertive } \\
\text { Communication }\end{array}$ & 18 & 12,2 \\
\hline & Total & 147 & 100 \\
\hline
\end{tabular}

Table 2 shows that the majority of respondents have aggressive communication that is equal to 98 respondents $(66.7 \%)$ and only a small proportion of respondents who have assertive communication skills are as many as 18 respondents $(12.2 \%)$.

Table 3. Assertive Communication Skills of respondents based on Gender

\begin{tabular}{|c|c|c|c|c|c|}
\hline No. & $\begin{array}{c}\text { Category of } \\
\text { communication } \\
\text { capability }\end{array}$ & Male & Female & $\mathrm{f}$ & $\%$ \\
\hline 1 & $\begin{array}{c}\text { Aggressive } \\
\text { Communication }\end{array}$ & $\begin{array}{c}68 \\
(46,2 \%)\end{array}$ & $\begin{array}{c}30 \\
(20,4 \%)\end{array}$ & 98 & 66,7 \\
\hline 2 & $\begin{array}{c}\text { Passive } \\
\text { Communication }\end{array}$ & $\begin{array}{c}12 \\
(8,2 \%)\end{array}$ & $\begin{array}{c}19 \\
(12,9 \%)\end{array}$ & 31 & 21,1 \\
\hline 3 & $\begin{array}{c}\text { Assertive } \\
\text { Communication }\end{array}$ & $\begin{array}{c}7 \\
(4,8 \%)\end{array}$ & $\begin{array}{c}11 \\
(7,5 \%)\end{array}$ & 18 & 12,2 \\
\hline & Total & 94 & 53 & 147 & 100 \\
\hline
\end{tabular}

Table 4. Table of Frequency Distribution of Respondents by Assertive Communication Category (ASA instrument categorization)

\begin{tabular}{|c|c|c|c|c|}
\hline \multirow{2}{*}{ No } & \multirow{2}{*}{ Component } & \multicolumn{3}{|c|}{ Communication } \\
\hline & & Aggressive & Passive & Assertive \\
\hline 1 & $\begin{array}{c}\text { The ability to } \\
\text { express } \\
\text { positive } \\
\text { feelings }\end{array}$ & $\begin{array}{c}92 \\
(62,6 \%)\end{array}$ & $\begin{array}{c}25 \\
(17,2 \%)\end{array}$ & $\begin{array}{c}30 \\
(20,2 \%)\end{array}$ \\
\hline 2 & $\begin{array}{c}\text { The ability to } \\
\text { express } \\
\text { negative } \\
\text { feelings; the } \\
\text { ability to say } \\
\text { "no" }\end{array}$ & $\begin{array}{c}79 \\
(53,4 \%)\end{array}$ & $\begin{array}{c}35 \\
(23,9 \%)\end{array}$ & $\begin{array}{c}33 \\
(22,6 \%)\end{array}$ \\
\hline 3 & $\begin{array}{c}\text { The ability to } \\
\text { defend } \\
\text { personal } \\
\text { rights }\end{array}$ & $\begin{array}{c}90 \\
(60,9 \%)\end{array}$ & $\begin{array}{c}34 \\
(23,4 \%)\end{array}$ & $\begin{array}{c}23 \\
(15,7 \%)\end{array}$ \\
\hline
\end{tabular}

Based on table III, it can be interpreted that the majority of respondents have the ability to communicate aggressively on the component of the ability to express positive feelings as many as 92 respondents $(62.6 \%)$ and the ability to defend personal rights as many as 90 respondents (60.9\%), and only a small portion respondents who have assertive communication skills in maintaining personal rights are as many as 23 respondents $(15,7 \%)$.

Assertiveness is characterized as the ability to maintain personal rights and needs while respecting others; unassertive or submissive is characterized as a person's subordinate rights and the needs of others and social challenges; and aggressiveness is an effort to meet one's needs by denying or ignoring the rights of others [21]. The data in table III shows that almost half of the male respondents are in aggressive communication skills as many as 68 respondents $(46.2 \%)$, this figure shows a higher number compared to aggressive communication that occurs in female respondents that is equal to 30 respondents (20, $4 \%)$.

Seeing the results of the above research, it can be concluded that between young men and young women has the same opportunity to have aggressive communication. The research was reinforced with previous studies explaining that male students and female students have the same relative tendency to perform aggressive behaviors [22]. The difference is if adolescent male aggressive behavior tends to be proactive and reactive to certain situations with peers, whereas girls are more toward aggressive behavior related to relational - emotional/ romantic [23].

Other studies have also mentioned that male adolescents are more often involved in fights or interpersonal issues with peers, although for teenage girls it still needs to get attention related to aggressive behavior, because The pro social young women are also quite high [22]. Hsiao's statement is also in line with other studies explaining that there is a difference in aggressive behavior in men and women as well as being influenced by various factors, including personality and social factors. Females tend to be sympathetic than men, this is what makes the women are not always indicative of physical aggressive behavior [24] [25].

A small proportion of respondents with experience of aggressive behavior have the ability to communicate unassertive or passive communication, as many as 12 male respondents (8.2\%) and 19 female respondents (12.9\%). Passive communication is communication carried out with the aim of avoiding conflict or confrontation with the other party to keep creating an atmosphere of peace and calm. Individuals tend to succumb to maintain relationships that have been established, even at the expense of personal interests [26].

The difficulty of adolescents in refusing their friends' invitations can be caused by failures in establishing good interpersonal communication as well as personal anxiety or fear if later shunned and ostracized by their friends [27]. This fear and anxiety make these students reluctant to develop assertiveness so they tend to take part in things done by their social groups [28]. In addition, respondents with a history of aggressive behavior experience, they have a low tendency to engage in passive communication [29] because with the experience of aggressive behavior that teenagers have in the early stages of communication more often in the form of threatening if something happens, this is associated with achieving emotional development maturity, so adolescents aged 12-14 years more often use threats to manifest their aggressive behavior compared to direct action [30]. Although passive people may not always be happy with the decisions made by others, it usually seems easier to 
go along with the decisions and keep the peace rather than make a fuss [31]. However, given time passive people may start to resent the fact that their needs are always over looked. The result may be low self-esteem, depression, anger, and many other emotional or physical complaints [32]. Also, people who are very passive often lose the respect of others if they fail to stand up for their rights [33].

While for assertive communication skills, both male and female respondents were only a small proportion of respondents who had assertive communication skills in the amount of 7 male respondents $(4.8 \%)$ and 11 female respondents $(7.5 \%)$. In addition, adolescents who have a history of aggressive behavior every behavior or communication they do has the aim to express their feelings of discomfort to the environment before they will be hurt by others [34] [35].

\section{CONCLUSION}

The results showed that the assertiveness of communication skills in adolescents with a history of aggressive behavior was still low, where the highest type of communication skills possessed by adolescents was aggressive communication skills. Based on the category of the Assertiveness Scale for Adolescent shows that the highest component of communication skills possessed by adolescents with a history of aggressive behavior is the ability to express positive feelings, the ability to express negative feelings, and the ability to defend personal rights is largely in the aggressive communication category

\section{ACKNOWLEDGMENT}

The researcher wants to acknowledge Kadiri University, especially the Health Science Faculty, for giving a chance for doing the research and composing the report.

\section{REFERENCES}

[1] M. Peeters, W. A. M. Vollebergh, R. W. Wiers, and M. Field, "Psychological Changes and Cognitive Impairments in Adolescent Heavy Drinkers," Alcohol Alcohol., vol. 49, no. 2, pp. 182-186, 2014.

[2] E. M. Yunalia and A. N. Etika, "Effectiveness of Assertiveness Training Group Therapy on Assertive Communication Ability in Adolescents with Aggressive Behavior," J. Keperawatan Jiwa, vol. 7, no. 3, pp. 229 236, 2019.

[3] J. A. Silvers et al., "Emotion Age-Related Differences in Emotional Reactivity, Regulation, and Rejection Sensitivity in Adolescence Age-Related Differences in Emotional Reactivity, Regulation, and Rejection Sensitivity in Adolescence," Am. Psychol. Assoc., pp. 114, 2012.

[4] M. Fatchurahman, "Self-Confidence, Emotional Maturity, Democratic Parenting Parents and Juvenile Delinquency," Pers. Psikol. Indones., vol. 1, no. 2, pp. 77-87, 2012.

[5] D. Lutfiani, Sri, and P. Setyawati, "The Relationship Between Emotional Intelligence and Aggressive Behavior of Grade VIII Students of SMP Negeri 8 Kediri Academic Year 2017/2018," Simki-Pedagogia, vol. 02, no. 03, 2018.
K. L. Herts, K. A. Mclaughlin, and M. L. Hatzenbuehler, "Emotion Dysregulation as a Mechanism Linking Stress
Exposure to Adolescent Aggressive Behavior," J. Abnorm. Child Psychol., vol. 40, pp. 1111-1122, 2012.

[7] S. A. Myers, M. Brann, M. M. Martin, S. A. Myers, M. Brann, and M. M. Martin, "Identifying the Content and Topics of Instructor Use of Verbally Aggressive Messages Identifying the Content and Topics of Instructor Use of Verbally Aggressive Messages," Commun. Res. Reports, vol. 30, no. 3, pp. 252-258, 2013.

[8] A. Shao, L. Liang, C. Yuan, and Y. Bian, "A Latent Class Analysis of Bullies, Victims and Aggressive Victims in Chinese Adolescence: Relations with Social and School Adjustments," PLoS One, vol. 9, no. 4, 2014.

[9] WHO, "Global Status Report on Noncommunicable Diseases," 2010.

[10] L. Riley et al., "The World Health Organization STEPwise Approach to Noncommunicable Disease RiskFactor Surveillance: Methods, Challenges, and Opportunities," Am. J. Public Health, vol. 106, no. 1, pp. 74-86, 2016.

[11] Y. Hsiao, C. Cheng, and Y. Chiu, "Gender Network Dynamics in Prosocial and Aggressive Behavior of Early Adolescents," Soc. Networks, vol. 58, pp. 12-23, 2019.

[12] H. H. Freudenthaler, E. Hofer, N. Pichler, E. M. Weiss, and I. Papousek, "Potential Markers of Aggressive Behavior: The Fear of Other Persons' Laughter and Its Overlaps with Mental Disorders," vol. 7, no. 5, 2012.

[13] E. M. Yunalia, "Relationship between Self-Concept and Acceptance of Physical Changes in Young Women in Puberty,” Nurs. Sci. J., vol. 1, pp. 30-36, 2017.

[14] R. F. Amalia and B. A. Keliat, "Assertive group therapy Improves Assertiveness and Resilience in Adolescents at Padang Panjang Public Middle School," J. Keperawatan Indones., vol. 21, no. 1, pp. 60-68, 2018.

[15] KPAI, "Child Complaints Case Data Table Based on Child Protection Cluster," 2016.

[16] I. Z. Arofa, Hudaniah, and U. Zulfiana, "The Effect of Bullying Behavior on Empathy Judging from the Type of School," J. Ilm. Psikol. Terap., vol. 06, no. 01, pp. 74-92, 2018.

[17] Jatimprov, "Evaluation Results of RKPD Implementation and Performance of Government Administration," pp. 1467, 2019.

[18] A. Mar, A. Hasanah, and S. Saraswati, "Effect of Peoples's Behavior to Student Assertivity," Indones. J. Guid. Couns. Theory Appl., vol. 4, no. 1, pp. 22-29, 2015.

[19] S. Khalisah and R. Lubis, "Differences in Assertive Behavior Judging from Parenting Parents in Adolescents who Have Clique," J. Divers., vol. 2, no. 1, pp. 10-22, 2016.

[20] K. Dewi, "The Effect of Group Counseling Services with Sociodrama Techniques on Student Assertive Behavior," Indones. J. Guid. Couns. Theory Appl., vol. 6, no. 3, 2017.

[21] Ł. Nikel, "Submissiveness, Assertiveness and Aggressiveness in School-Age Children: The Role of Self-Efficacy and the Big Five," Child. Youth Serv. Rev., vol. 110, no. January, pp. 1-6, 2020.

[22] D. Murray-Close, J. M. Ostrov, D. A. Nelson, N. R. Crick, and E. F. Coccaro, "Proactive, Reactive, and Romantic Relational Aggression in Adulthood: Measurement, Predictive Validity, Gender Differences, and Association with Intermittent Explosive Disorder," J. Psychiatr. Res., vol. 44, no. 6, pp. 393-404, 2010.

[23] W. Nanda E. Saputra, N. Hanifah, and D. N. Widagdo, "Differences in Aggression Behavior Levels Based on Gender in Vocational High School Students in Yogyakarta City," J. Kaji. Bimbing. dan Konseling, vol. 2, no. 4, pp. 142-147, 2017. 
[24] A. Merdekasari and M. T. Chaer, "Difference in Aggression Behavior between Male and Female Students at SMPN 1 Kasreman Ngawi," J. Psikol. Pendidik. Konseling, vol. 3, no. 1, pp. 53-60, 2017.

[25] M. V. Mestre, P. Samper, M. D. Frías, and A. M. Tur, "Are Women More Empathetic than Men? A Longitudinal Study in Adolescence," Span. J. Psychol., vol. 12, no. 1, pp. 76-83, 2009.

[26] S. Bossuyt and P. Van Kenhove, "Assertiveness Bias in Gender Ethics Research: Why Women Deserve the Benefit of the Doubt," J. Bus. Ethics, 2016.

[27] G. Bosmans, C. Braet, W. Beyers, and K. Van Leeuwen, "Parenting: Science and Practice Parents' Power Assertive Discipline and Internalizing Problems in Adolescents: The Role of Attachment Parents' Power Assertive Discipline and Internalizing Problems in Adolescents: The Role of Attachment," Parent. Sci. Pract., vol. 11, no. 1, pp. 37-41, 2015.

[28] R. M. Putri and T. Wahyuni, "The Effect of Group Guidance on Assertive Behavior of Students in Srijaya Negara Junior High School," J. Bimbing. dan Konseling Terap., vol. 02, no. 02, pp. 178-183, 2018.

[29] T. Ojanen, D. Findley, and S. Fuller, "Physical and Relational Aggression in Early Adolescence: Associations with Narcissism, Temperament, and Social Goals," Aggress. Behav., vol. 38, pp. 99-107, 2012.

[30] D. V Poling, S. W. Smith, G. G. Taylor, and M. Worth, "Direct Verbal Aggression in School Settings: A Review of the Literature," Aggress. Violent Behav., 2019.

[31] M. J. Ruiz and A. Baaklini, "Individual and Social Correlates of Aggressive Behavior in Lebanese Undergraduates: The Role of Trait Emotional Intelligence," J. Soc. Psychol., vol. 158, no. 3, pp. 350360, 2018.

[32] J. Jang et al., "Predictors of Suicidal Ideation in a Community Sample: Roles of Anger, Self Esteem, and Depression," Psychiatry Res., vol. 216, no. 1, pp. 74-81, 2014.

[33] G. Sitota, "Assertiveness and Academic Achievement Motivation of Adolescent Students in Selected Secondary Schools of Harari Peoples Regional State, Ethiopia," Int. J. Educ. Lit. Stud., vol. 6, no. 4, pp. 40-46, 2018.

[34] E. Estévez, T. I. Jiménez, and D. Moreno, "Aggressive behavior in adolescence as a predictor of personal, family , and school adjustment problems," Psicothema, vol. 30, no. 1 , pp. 66-73, 2018.

[35] H. C. Galloway, "The Future of Adolescent Female Cyber-Bullying: Electronic Media's Effect on Aggressive Female Communication," 2007. 